Article

\title{
Religion and Genocide Nexuses: Bosnia as Case Study
}

\section{Kate E. Temoney}

Department of Religion, Montclair State University, Dickson Hall 450, 1 Normal Avenue, Montclair, NJ 07043, USA; temoneyk@montclair.edu

Received: 3 April 2017; Accepted: 8 June 2017; Published: 14 June 2017

\begin{abstract}
Social scientists have been involved in systematic research on genocide for over forty years, yet an under-examined aspect of genocide literature is a sustained focus on the nexuses of religion and genocide, a lacuna that this article seeks to address. Four ways religion and genocide intersect are proposed, of which two will receive specific attention: (1) how religious rhetoric and (2) how religious individuals and institutions foment genocide. These two intersections are further nuanced by combining a Weberian method of typologies, the Durkheimian theory of collective violence, and empirical data in the form of rhetoric espoused by perpetrators and supporters of the 1995 Bosnian genocide. This combination yields the three typologies of "othering", justification, and authorization, which are further supported by a review of genocide literature. The typologies provide a framework for analyzing the synergistic relationship between religion and genocide in the interest of devising a model that can be applied to other genocides for investigative and comparative purposes and reveal that religion is both instrumentalized by individuals and institutionally instrumental in genocide perpetration. Individuals explicitly employ religious rhetoric to prey on the fear of the masses, and religious institutions and individuals are indispensable to lending religious justification and moral authority to genocidal campaigns. These results may serve as a starting point for devising strategies that neuter the destructive links between genocide and religion as well as leveraging the ambiguity of religion in favor of its constructive and obviating potential.
\end{abstract}

Keywords: Bosnian genocide; religion; religious rhetoric; genocide prevention

\section{Introduction}

Alex Alvarez, author of Governments, Citizens, and Genocide: A Comparative and Interdisciplinary Approach, observes that there is a lack of contributions by the social sciences to genocide literature. As reasons, he cites social science's ethnocentrism, its emphasis on empiricism rather than theory, and the "marginali[zation] of state or political crime", specifically in criminology (Alvarez 2001, pp. 3-9). The enumerated social sciences are sociology, political theory, history, anthropology, psychology, and philosophy; the field of religious studies is conspicuously absent from the conversation. This omission in genocide studies has been most recently filled by two edited volumes that focus primarily on the religious aspects of several genocides: Omer Bartov and Phyllis Mack's In God's Name: Genocide and Religion in the Twentieth Century (2001) and Steven Leonard Jacobs' Confronting Genocide: Judaism, Christianity, Islam (2009). The editors note, "not many scholars have looked either at the religious aspects of modern genocide, or at the manner in which religion has taken a position on mass killing" (Bartov and Mack 2001, p. 1). Moreover, " ... 'religion' is all too often overlooked as an important factor in contributing to either the implementation and perpetuation of genocide, or as a foundational underpinning and rationalization for such collective acts" (Jacobs 2009, p. ix). Notable exceptions to overlooking the salient role religion plays in genocide are book-length treatments of both the Rwandan genocide-Christopher C. Taylor's Sacrifice as Terror (1999) and Timothy Longman's Christianity 
and Genocide in Rwanda (2010)—and the Bosnian genocide_Paul Mojzes' Religion and War in Bosnia (1998) and Michael Sells' The Bridge Betrayed: Religion and Genocide in Bosnia (1996). The latter work significantly informs this investigation.

A likely reason for the inattention to intersections between religion and genocide is that religion is commonly understood to be a contributing but not a primary motivating factor in genocide perpetration. Philosopher John K. Roth, citing sociologist Kurt Jonassohn and historian Frank Chalk (1990), writes that Jonassohn and Chalk "persuasively [argue] that genocide—ancient or modern - typically involves one or more of at least four factors or motivational drives: "(1) 'to eliminate a real or potential threat'; (2) 'to spread terror among real or potential enemies'; (3) 'to acquire economic wealth'; or (4) 'to implement a belief, a theory, or an ideology'" (Roth 2010, p. 35). Twenty years after Jonassohn and Chalk's influential book, Roth argues for the inclusion of religion among the drives because "religion can be, and often is, an agitating factor, if not a central one, in any and all of those motivations. Precisely how religion may be a factor in those ways requires, of course, careful study of the particularities of each genocidal situation" (Roth 2010, p. 35). Furthermore, "political and economic competition among groups is frequently couched in religious terms, and attitudes toward members of other groups and ways of treating them are themselves understood religiously" (Little 1991, p. xx).

\section{Four Religion and Genocide Nexuses}

The first connection between religion and genocide is the designation of adherents of the same religion as a protected group per the Genocide Convention; the other protected groups are racial, ethnic, and national groups. Therefore, religion is one of many group identifiers that perpetrators can use to target a segment of the population for annihilation. This also includes ethnoreligious groups or communities that share both a common ethnicity and religious history fused into a single ethnoreligious identity, as was the case in the Former Yugoslavia during the genocide that primarily involved Eastern Orthodox Serbians targeting Bosnian Muslims or the slaughter of Christian Armenians by the Muslim Young Turks of the Ottoman Empire. Second, génocidaires also exploit religious language, using it to justify their ideology as well as to motivate individuals to commit acts of violence. Examples of this religious rhetoric include the promulgation of propaganda with religious overtones, explicit references to mythical religious hatreds, and the divinization of violence. This was evident in anti-Semitic films, magazine covers, and cartoons that depicted Jews as killers of Christ and styled Hitler as a savior-figure dutifully completing the work of the Lord by ridding humanity of the Jewish parasite (Jowett and O'Donnell 2006, p. 231; United States Holocaust Museum n.d.). The force of such rhetoric is that it re-imagines victims as actors in a sacred drama deserving of destruction that is often supported by textual exegesis and theological warrants.

Third, religious individuals (primarily members of the clergy) have both implicitly and explicitly condoned genocide, implicitly by remaining silent and explicitly by actively buttressing state propaganda or even by physically participating. In March 2017, after over two decades of the Vatican disavowing any responsibility for the 1994 genocide, Pope Francis asked for forgiveness for the role the Catholic Church played in the slaughter, lamenting the "sins and failings of the church and its members" (Sherwood 2017). The most devastating effect of these "failings" is that they seem to religiously sanction or commend genocidal behavior. Fourth, religion has sometimes played a pivotal role in the prevention or interruption of genocide and in caring for its victims. Most notably, religious individuals and institutions have forestalled genocidal killing by engaging in acts of resistance and heroism-such as engineering the sheltering or escape of members of the targeted group and their sympathizers-and facilitated after-care by providing aid to victims and lending support to reconciliation efforts. One of the most well-known and documented acts of heroism is the hiding and rescue of Danish Jews in Denmark as the Holocaust unfolded during World War II, and Catholic Relief Services (CRS) provided and continues to provide humanitarian relief to Rwanda post the 1994 genocide. Of the four connections between the phenomena of religion and genocide, the second and 
third-religious rhetoric as a catalyst for genocide and the involvement of the institutional church and religious actors in genocide-constitute the heart of this essay.

A focused investigation of the religious rhetoric and rituals deployed by members of the political and church hierarchy, which shaped and supported genocidal ideology, reveals the prominent role of religion in genocide perpetration. The claims herein are not that religion directly or uniquely causes violence or that genocide perpetrators who are among the faithful necessarily believe or espouse that they are doing "God's work". Rather, this project examines how demagogues and clerics alike invoke religious expressions, mythology, and symbolism in order to lend credibility to their genocidal activity. ${ }^{1}$ Moreover, the project also examines $w h y$ this strategy effectively convinces both the religiously observant and unobservant that the extirpation of an enemy group is an absolute imperative. One reason that may account for the effectiveness of religious discourse in convincing both the religious and non-religious among the citizenry is that framing a conflict in religious terms adds a dimension of gravity ${ }^{2}$ and urgency that resonates with the masses and amplifies conflict. The purchase of such discourse is not always due to the persuasiveness of the dogma or theological reasoning of a particular religious tradition. Rather, it is often due to the presumed aura of moral superiority, sacredness, and righteousness the use of religious discourse conveys, the presentation of the ultimate matters at stake, and the authorization of genocidal actions as legitimate and necessary public policy. Religious frameworks and justifications may be so convincing, given their sacral import, transcendent status, and absolute truth claims, that they can lead to extreme actions in defense of ultimate concerns. Hence, although religious belief is rarely the only driving factor in genocide, it is not merely ancillary to genocide but potentiates genocide in a particular manner due to its mythological, divine, and ontological referents that transcend everyday reality, are resistant to secular critique, and heighten the issues at stake in a conflict.

\section{Investigatory Foundations: Method, Theory, and Rhetorical Data}

The approach in this article brings together method, theory, and empirical data: Weberian method, Durkheimian theory, and empirical data in the form of rhetoric espoused by perpetrators and supporters of the 1995 Bosnian genocide. Peter L. Berger, author of The Sacred Canopy: Elements of a Sociological Theory of Religion (1990), cites the advantage of a tandem use of Max Weber and Émile Durkheim's schools of thought, claiming that a "dialectic understanding of man and society as mutual products makes possible a theoretical synthesis of the Weberian and Durkheimian approaches to sociology without losing the fundamental intention of either" (Berger 1990, p. 187, n. 2). Here, Berger is referring to Weber's privileging of subjectivity and an emphasis on the individual's effect on society versus Durkheim's objectivity and emphasis on society's effect on the individual. The research approach proposed herein extends this intellectual symbiosis by coupling Weber's method with Durkheim's hermeneutics.

Employing religion as a disciplinary tool for understanding genocide, the virtue of Weber's theoretical approach is primarily his sociological method, which provides a research agenda for investigating a societal phenomenon using ideal types. Weber's 1922 posthumously published book, Economy and Society, was a groundbreaking work in the discipline of sociology, in which Weber introduced the concepts of "pure types" or "ideal types" as a way of organizing empirical data without claiming that such an approach could entirely account for all the complexities of social realities or "action-orientations". Rather, "ideal types are constructions-models—designed above all to facilitate

1 As a complement to the use of rhetoric by perpetrators to further genocidal aims, see (Basic 2017) for an account of the use of rhetoric from the perspective of the victim as a form of resistance.

2 The weight and implications of the use of the word "genocide" is analogous to this gravity. Surely, part of what fuels the debate over whether a conflict is a genocide or not has just as much to do with whether the conflict meets the legal standard of genocide as much as it has to do with the desire to signal a moral indignation that can only be adequately expressed by considering a conflict to be "the crime of crimes". Just as the invocation of genocide communicates a crime beyond the pale, so too does religious language communicate the seriousness of what is at stake; perception becomes reality. 
empirical inquiry" (Kalberg 2012, p. 130). Furthermore, Weber's keen interest in religious worldviews and the power of religious action as a social domain make his method particularly suitable for analyzing the intersections of religion and genocide. Weber's method attends to the status of religion as an integral part of human existence, an argument against considering religion only to be of peripheral importance when studying human behavior and communities; Weber readily recognized that human beings have a desire to legitimate their social standing in non-secular terms. David Little quotes Weber when he writes that collectives " wish to see their positions transformed from purely factual power relations into a cosmos of acquired rights, and to know that [those rights] are sanctified'" (Little 1991, p. xx). Little correctly summarizes Weber's sentiment when he writes: "Human beings seem compelled to evaluate given political and economic arrangements in reference to sacred or cosmic standards", which suggests that "religious and related beliefs play a role in human experience and are more than simply the function of some prior material or external condition" (Little 1991, p. xx). This human tendency to demarcate groups establishes "outsiders" and "insiders", which underpins Weber's stance on religious nationalism and substantiates the role of religious rhetoric during the commission of genocides as the ultimate consequence of radical differentiation.

The virtue of Durkheim's theoretical orientation is primarily his sociological account and interpretation of human behavior, which frames religion as a functional component or a set of beliefs and practices, which can contribute to the commission of genocide. Durkheim's functional approach to religion, as exemplified by his famous assertion that "religion is eminently social", is useful for understanding the role that religion can play in promoting mass violence. One such concept is "collective effervescence", which first appeared in Durkheim's Formes élémentaires de la vie religieuse (1912):

The effervescence often becomes so intense that it leads to outlandish behavior; the passions unleashed are so torrential that nothing can hold them. People are so far outside the ordinary conditions of life, and so conscious of the fact, that they feel a certain need to set themselves above and beyond ordinary morality. (Stone 2004, p. 60, n. 13)

Religious rhetoric is particularly adept at facilitating collective effervescence due to absolute moral claims that render otherwise immoral behavior as praiseworthy. Killing one's neighbor for no other reason than their accidental membership in a particular group is certainly "outlandish behavior", but eliminating an ontologically evil threat that offends the cosmological order is not.

The typologies of "othering", justification, and authorization are based on empirical data in the form of an assessment of religious rhetoric espoused by politicians, religious actors, and genocide perpetrators involved in the 1995 Bosnian genocide from interviews, speeches, and radio broadcasts as found in primary and secondary sources. "Othering" is styling the target group as an essentialist enemy and radically different from the perpetrator group; justification is creating ideologies that legitimate the elimination of the enemy group; and authorization is conferring or reinforcing the right to act upon a justification and leveraging the power to do so. These typologies are further supported by a review of literature on the topic of religious violence, including religion and genocide, which consistently yields the emergence of, in one form or another, these three concepts. For example, "othering" is illustrated in Alexander Laban Hinton's Annihilating Difference: The Anthropology of Genocide (2002) and Mahmood Mamdani's When Victims Become Killers: Colonialism, Nativism, and the Genocide in Rwanda (2001). Hinton uses the language of "difference" and Mamdani the nomenclature of "alien" to capture the conceptualization of the group targeted for destruction. In his Purify and Destroy: The Political Uses of Massacre and Genocide (2007), Jacques Semelin outlines justifications for annihilation, what he calls "delusional rationality". Further, Bartov and Mack illustrate in In God's Name (2001) their central interest in identifying how humans have historically invoked religion to resist violence as well as how people have used religion to legitimize mass murder by recoding a conflict as a "cosmic struggle" that permits killing for a greater good. Authorization, in the form of textual warrants, is a main focus of several works, such as Jacobs' edited volume, Confronting Genocide: Judaism, Christianity, and Islam (2009); Charles Selengut's Sacred Fury: Understanding Religious Violence (2003); Mark Juergensmeyer's Terror in the Mind of God: The Global Rise of Religious Violence (2001); and Timothy Longman's Christianity 
and Genocide in Rwanda (2010). Each work locates the authorization for genocide in a divine mind, which "mandates" or makes certain action a religious "duty", and in the case of the latter text, situates genocide within the context of "obedience" to the Church, politicians, and church officials who wield a moral authority with the citizenry.

The 1995 Bosnian genocide is a well suited and, unlike many other genocides, well-researched case study of the intersections of religion and genocide. Per Charles C. Ragin and Howard Saul Becker's conceptual maps in What is a Case?: Exploring the Foundations of Social Inquiry (1992)", this inquiry views the Bosnian genocide as among the "Cases are objects" approaches; the virtue of this strategy is that it treats the Bosnian genocide as "empirically real and bounded, but specific" (Ragin and Becker 1992, pp. 9-10), and also as a particular case that can be the basis for developing a generalizable framework for teasing out the intersections of religion and genocide in other conflicts. A key facet of genocide incitement and commission in the Bosnian genocide was the role of religious rhetoric, mythology, and symbolism, particularly when espoused or tacitly condoned by perceived "legitimate" religious and political authorities. The appropriation of religious language and symbols were a central component in persuading perpetrators to believe (or pretending to believe) that their murderous and sexually barbarous actions were condonable, and rhetoric is a source for locating how "othering", justification, and authorization are operant in perpetrator ideology. Attending to the potency of religious rhetoric is a starting point for understanding how religious language opens a space for violence and why it is so persuasive, regardless of whether génocidaires or the general citizenry consider themselves religious or not. The typologies of "Othering", justification, and authorization reinforce and mingle with each other in significant ways, but singling out each of these ideal types provides a starting point for investigating the complexity of their interaction. Before examining how religious rhetoric and actors potentiated genocide using the typologies, a review of the 1995 Bosnian genocide is necessary.

\section{The 1995 Bosnian Genocide in Brief}

The President of Serbia during the genocide, Slobodan Milošević rose to prominence and power with a two-fold platform: the Kosovo question and the Serb question (Udovički 1995, p. 297). The Kosovo question pertained to the autonomy of the Albanian minority occupying the province of Kosovo-Metohija, a status of autonomy due in large part to the former President of Yugsoslavia, Josip Broz Tito. The province belonged to Serbia and had long been held as the heartland of Serbian culture, history, and its spiritual lifeblood. When Kosovo demanded that its autonomous status be upgraded to that of a republic in 1981, the possibility of Kosovo seceding from Yugoslavia and joining Albania, taking the very seat of Serbia's national and religious consciousness with it, was unfathomable. The second question concerned Serbs who lived in Croatia and Bosnia-Herzegovina who were purportedly being persecuted and fleeing the country. In response to both the Kosovo and Serb questions, Milošević called for the restoration of Serbia to its past and mythical glory, which entailed the creation of a "Greater Serbia". Contending that Croatian Catholics and Bosnian Muslims were traitorous Orthodox Serb converts and a danger to the very existence of all Serbs, Milošević set out to create an ethnically homogenous and mono-confessional Serbian state that included Kosovo and Bosnia-Herzegovina.

Following the declared independence of Bosnia-Herzegovina in April of 1992, Serb nationalist insurgents activated plans for the mass expulsion of non-Serbs from Croatia and Bosnia, but the Muslims of Bosnia-Herzegovina ("Bosniaks") were the most heavily victimized group during the war and will be the focus of this study. ${ }^{3}$ Fueled by atavistic propaganda, Milošević and his political

3 Catholic Croat and Bosnian Muslim clerics also inflamed their fellow coreligionists using religious rhetoric, and Croat militias joined Serbs forces in the victimization of Bosniaks. However, in the interest of focus, this chapter examines the role of religion in Serbian nationalism and the complicity of the Serbian Orthodox Church in the genocide in Srebrenica with 
associates deployed the Yugoslav National Army (JNA) and Serb paramilitaries in an attempt to create (or recreate) ${ }^{4}$ a "Greater Serbia" through mass killing (including Serb dissidents), systematic rape, torture, deportation, and imprisonment. The most widely reported and most intense fighting occurred in Bosnia-Herzegovina. Commanded by Ratko Mladić, the Army of Republika Srpska (VRS) massacred 7000-8000 (International Criminal Tribunal for the Former Yugoslavia 2005) Muslim men and boys in the Bosnia-Herzegovina enclave of Srebrenica in 1995. Srebrenica had the highest death toll of any single attack during the war, and it is the only crime for which perpetrators have been found guilty of genocide ${ }^{5}$ in a conflict that is otherwise primarily considered a campaign of ethnic cleansing. The signing of the Dayton Accords in December 1995 officially ended the war and divided Bosnia into two Republics with its own president. By the war's end, there were 100,000 fatalities (Ball et al. 2007), most of whom were Bosniaks.

A panoply of scholarship ${ }^{6}$ substantiates that ethnic cleansing and genocide were prominently attended by religious rhetoric, public documents, symbolic ceremonies, and mythologies by politicians and clergy alike; and the Serbian Orthodox Church (Srpska Pravoslavna Crkva) was indispensable to framing, justifying, and successfully executing the Serbian agenda to eliminate Bosnian Muslims. Noting how "religion contributed greatly to reawakening and amplifying the Serbian nationalist cause", Semelin offers Radovan Karadžić, the President of the Republika Srpska and accused by the International Criminal Tribunal for the Former Yugoslavia (ICTY) of ordering the Srebrenica genocide, as an example of the state/church alliance. On several occasions, Karadžić's public comments about how to resolve the "Kosovo question" were a permutation of the same claim, "nothing can be done without the Church" (Semelin 2007, p. 86). Hence, before turning to the three typologies, a brief review of the mythology that inspired the religious rhetoric that fed nationalism and the ensuing genocide as well as a summary of the Serbian Orthodox Church is required to foreground the typologies.

\section{The Birth of a Mythology: The Serbian Golgotha}

At the center of the ideology of the Bosnian genocide and campaign of ethnic cleansing is the pivotal role that Kosovo plays in Serbian consciousness, the story of which often begins with the 28 June 1389 Battle of Kosovo and Prince Lazar Hrebeljanovic's death at the hands of Ottoman Turks led by Turkish Sultan Murat at the Field of Blackbirds (Kosovo Polje). Both men were killed. Lazar is said to have elected the kingdom of heaven, "to die in battle rather than live in shame" (Judah 2000, p. 90), rather than secure an earthly empire when given the choice by God to live in wealth or die as a Christian solider. Lazar's sacrifice solidified his martyrdom and marked what would be the beginning of the 500-year domination of the Ottoman Empire. Over the course of the centuries, Prince Lazar would be styled as a Christ figure and was memorialized and immortalized in art and literature. The singularly most influential work among this literature was a play written in verse, The Mountain Wreath (1847), penned by prince and bishop Petar II Petrović, known as Njegoš. The sanctification of Lazar was complete with his death referred to as the "Serbian Golgotha" and paintings of Lazar flanked by "knight-disciples" at a "last supper" who was betrayed by a Judas, Vuk Brankovic, who gave Serbian battle plans to the Ottoman army (Sells 2001, pp. 180-81).

incidental attention to other ethnoreligious groups, ethnic cleansing, and geographical locations insofar as they contribute to the primary focus.

4 This nationalist goal reached back to the nineteenth-century when the autonomy and independence of Serbia was largely realized by the end of the nineteenth century; hence, "Greater Serbia" ideology also harkened back to a romanticized golden age for Serbia.

5 Prosecutor v. Radislav Krstić, Judgment, Case No. IT-98-33-A, April 19, 2004; Prosecutor v. Blagojević, Judgment, Case No. IT-02-60-T, January 17, 2005. The judgment in the trial of Ratko Mladić is expected in November 2017. Among his charged crimes are two counts of genocide, one of which is for the role he played in the massacre in Srebrenica. See (The United Nations International Criminal Tribunal for the former Yugoslavia n.d.).

6 See (Sells 1996; Paul 1998; Johnston and Eastvold 2004; Semelin 2007). 
At the same time, Brankovic, who converted to Islam, would come to represent all Slavic Muslims who are "Christ-killers", "race-traitors" and "Turks", while a Serbian Knight, Miloš Obilić, would become a venerated saint for avenging Lazar's death by assassinating Sultan Murad (Sells 2001, pp. 182-83). During the genocide, and even today, Serb and Croat nationalists use these monikers "based upon the ideology of Christoslavism. [According to this theory] Slavs are held to be Christian by nature. Any conversion then is not only a betrayal of the Slavic people or race, but an actual ethnic or racial transformation. To convert to Islam is to become a Turk". (Sells 2001, pp. 182-83) The Battle of Kosovo and Prince Lazar figured prominently in speeches by both politicians and clergy, framing the genocide as a defensive strike by the perpetually victimized Serbs against the Muslim Turks bent on the demise of Serbians. As one might imagine, the magnitude of this threat was maximized by its invocation during St. Vitus Day or Vidovdan, the commemoration of the June 281389 Battle of Kosovo.

\section{The Serbian Orthodox Church}

To best account for the role of the Serbian Orthodox Church in the genocide requires a more nuanced history that dates back to the end of the two hundred-year Nemanjic dynasty (the legacy of which still reverberates in contemporary Serbia) and the death of Emperor Stefan Dusan in 1355 (Judah 2000, p. 89), thirty-six years before the Battle of Kosovo. According to Tim Judah, the brief but glorious Nemanjic dynasty, even under Ottoman rule and the collapse of Serbia, "gave the Serbs the wherewithal to survive as the nation they are today ... [because] a Serbian Orthodox autocephalous (i.e., national) church was founded by Ratsko, the son of King Stefan Nemanja, in 1219". (Judah 2000, p. 90) Autocephaly also meant that the church was (and still is) independent from an international structure, which has "largely facilitated the nationalization of religion and, at the same time the sacralization of the nation" (Buchenau 2009, p. 1). Tim Judah exemplifies this state of affairs when he writes, "the Serbs retained, in the church, a powerful national institution. Its survival meant that it was then able to propagate the notion that, just as Christ had been resurrected, so would Serbia" (Buchenau 2009, p. 1). Ottoman rule of Serbia began in 1459, and Serbia would not be "resurrected" until after the first Balkan War of 1912 when Serbia regained Kosovo.

A striking component of the ethnic cleansing campaign and genocide was the copious usage of incendiary religious language and imagery that were interwoven into nationalistic aims and acts of violence. Indeed, the conflict in Bosnia was a "religious genocide" in the sense that Bosnians, as well as Croatians, were singled out for their religious affiliation; clerics blessed and supported the violence ideologically and logistically; and religious mythologies and rituals framed the conflict as a sacred struggle between good and evil, apotheosizing Serbia nationalists in the process. Moreover, members of the Serbian (and Croatian) military marched with religious symbols; Serb Orthodox soldiers forced Bosnian Muslim and Catholic Croat prisoners to sing Christian folks songs; and soldiers also sang them as they slit the throats of their captives; and crucifixes dangled from the necks of soldiers who raped Muslim women in the Srebrenica prison camp.

\section{7. "Othering", Justification, and Authorization}

In the former Yugoslavia, "othering" took the shape of antagonisms among ethnic groups for which religion acted as a way of reinforcing communal boundaries. The ethnoreligious identities of Serbian Orthodox, Catholic Croat, and Bosnian Muslim symbolized inescapable memories of historical grievances and loyalties, whereby Croats came to represent the fascist Ustaše of World War II and evil Bosnians Christ-killers of the martyred Prince Lazar in the fourteenth century. Demagogues and the Serbian Orthodox Church hierarchy justified the annihilation of Bosnian Muslims by framing them as a danger to Serbians - physically, politically, and spiritually—a danger that was made more immediate and credible through the use of mythic time, making past threats to Serbian security present. Propagandists insisted that Bosniaks sought to directly kill, demographically overtake (through high birth rates), and subjugate Serbs to an Islamic state at the expense of Christianity, an assault that required a defense of genocidal proportions. The orchestration of the state apparatus (largely regarded 
as responsible for the rule of law and order) with the institutional church (largely regarded as a bastion of morality) enhanced the perceived legal and moral right of the state to act upon justifications for genocide. The Serbian Orthodox Church did not initiate the genocide or the campaign of ethnic cleansing, but the abetment of the Church reinforced the state's already existing legal standing. Although some public dissent was voiced by clergy, the blessings that many clergy bestowed on the violence by ritualizing acts of cleansing largely supported the genocidal aims of Milošević's regime. Moreover, genocide benefited the desire of Serbian Orthodox Church officials to maintain an influential role in Serbian political and cultural life.

\section{8. "Othering"}

The "othering" of the target groups in the former Yugoslavia included the two-pronged strategy of the demonization of their enemies' identities through the deployment of incendiary rhetoric. This included the potentiating element of religion in the forms of an ethnoreligious identity and religionational discourse coupled with the further distancing of Serbs from their enemies as a distinctive and exclusive "heavenly" or chosen people. The mythologized Battle of Kosovo found in The Mountain Wreath was central to the genocidal ideology that began developing in the few years leading up to the wars in the former Yugoslavia, and its influence cannot be overstated. Vasa D. Mihailovich believes that "no other event in Serbian history has had a greater impact on Serbian literature than the Battle of Kosovo. That one event has imprinted itself indelibly on the Serbian soul forever. It takes the central position in the body of epic poetry: everything seems to lead to and emanate from it" ((Mihailovich 1991, p. 141) quoted in (Khan 1997, p. 295)). Njegoš' epic shifted an enmity between Orthodox Serbians and Slavic Muslims "from the realm of blood feud into a cosmic duality of good and evil; Slavic Muslims become the 'other,' ... [and] "killing ... Turkified ones becomes not only worthy, but sacred, raised to the same level of sacrality as baptism or confession" (Sells 1996, pp. 42-43).

"In religionational policies and military operations, the first step toward the destruction of the enemy is symbolic inferiorization and dehumanization ... [and] in ... religionational discourse, they are cursed by God" (Velikonja 2003, p. 32). Serbian nationalists "labelled the Bosniaks as jihad fighters [wagers of a holy war], mujahidins [radical Islamicists], janissaries [Turkish militia members], and brothers in fez [again referring to the Bosniak's Turkish origins], whose final ambition was to turn Bosnia into ... a fundamentalist state, or a Libya-style Jamahiriyah, in which non-Muslims would become slaves" (Velikonja 2003, p. 32). Despite substantial periods of peaceful co-existence, ethnic turmoil was framed as a perennial problem that required a definitive resolution. Religion acted not only as a community identifier but also as indicator of Serbian nationalist fidelity or infidelity:

Muslim Slavs ... always posed a very vexing problem for Serbian nationalists. They were clearly descendants of fellow Slavic tribes, but in their very midst espoused the faith of the accursed "Turks" in direct opposition to whom Serbian national consciousness first emerged [in the 1389 Battle of Kosovo against the Muslims of the Ottoman Empire]. The mere existence of this South Slav Islamic population problematized and undermined the basic truth claims of Serbian nationalism. By transgressing imagined national boundaries, European Muslims ... embodies in their very being an existential problem which could only be solved through expulsion where practical, and extermination when not. (Khan 1997, pp. 291-92)

Ultimately, although the Ottoman Empire's geographic and ruling presence was in Europe it was never considered to be religiously or culturally of Europe (Khan 1997, p. 291). Bosnian Muslims were "the great historic 'Other' for both Serb as well as for much of the European continent due to their Ottoman heritage" (Khan 1997, p. 287). Not just different, the "other" falls outside of ordinary human relations and regard and even forfeits divine protection. The Turks' status as "other" was not due primarily to their "alien" status as foreigners to the land but to their betrayal of Serbian 
consciousness and nationalism by having converted to Catholicism or Islam. In converting, Serbians became estranged kin and were worse than foreigners; they were traitorous enemies within.

Well in advance of the disintegration of Yugoslavia, "influential figures in Serbia (including clergymen) had begun to shape a stereotypical image of Muslims as alien, inferior, and a threat to all that the Serbs held dear ... [and] by their very presence, obstructed...Belgrade's political goals" (Cigar 1995, p. 24). This lent itself to an "interpretation of political developments in religious terms", as exemplified by the:

analogies [that] were made between contemporaries and episodes and personalities from the Scriptures or the religious history ... In some Orthodox circles, for example, the Serbs were referred to as Christ's nation, the holy or suffering nation, the bearers of the truth and divine justice, the avant-garde of the Slav world and Orthodoxy. Serbia was again referred to as heavenly, and so on. (Velikonja 2003, p. 31)

Clerics, such as Metropolitan Amfilohije of Montenegro (Radovic), the bishop of the diocese of Montenegro, publicly supported the notion that "every nook of Serbian land and the Serbs themselves are a heavenly wonder, and an inspiration and example to all other peoples and countries". Such a divinization of Serbs further "othered" Muslims by increasing the mortal, and implied moral, distance between Serbs and all non-Serbs.

It [genocide] was religiously motivated and justified. Religious symbols, mythologies, myths of origin (pure Serb race), symbols of passion (Lazar's death), and eschatological longings (the resurrection of Lazar) were used by religious nationalists to create a reduplicating Miloš Obilić, avenging himself on the Christ killer, race traitor, alien, and ironically, the falsely accused "fundamentalist" next door. (Sells 1996, p. 89)

\section{Justification}

Religion initially was a central ingredient to "providing a mechanism for the ethnic separatism [othering] that was a primary political goal", and "religious rhetoric and religious symbols were used both to gain public support for the war and to provide a justification for Serb aggression, and the subsequent Bosniak response" (Herzfeld 2007, p. 110). While acknowledging the highly specific factors that culminate into a particular nation's genocide, Norman Cigar writes, "genocide is most likely to occur if the perpetrators regard it as a rational, cost effective strategy in pursuit of broader, concrete objectives" (Cigar 1995, p. 32). The establishment of such a rationale (if it does not already exist), serves the goals of perpetrators in mounting a convincing argument of defense, such as, there is no sacrifice too great for the sake of preserving an elected people and their Christian way of life. The Christ-killer and jihad accusations of the 1990s Balkan Wars were a culmination of "a modern surge in religious militancy after the cold war [and] a reappearance of a Serbian nineteenth-century ideology that constructs an 'age-old antagonism' between Muslims and Christians"' (Sells 1996, p. 90).

The quest for territorial and political expansion was fashioned as a counter-genocidal war of defense against an insidious enemy group using a hyperbolic religious narrative of good versus evil and mythologized histories. Far from stemming violence, the Serbian Orthodox Church authorized the Serbian nationalist genocidal and ethnic cleansing policy by eschewing non-violent resolutions and calls for a peaceful coexistence and instead "making force a morally acceptable means to use in Bosnia-Herzegovina" (Cigar 1995, p. 32). In March of 1992, the Serbian Orthodox Church released an article that appeared in an official journal, Pravoslavlje (Orthodoxy), apparently condemning Serbian "pacifism and defeatism", urging "Serbs to view [the] conflict in positive terms", and characterizing the conflict as a cosmic battle between good and evil that furthered God's plan for humanity's redemption

7 (Cigar 1995, p. 74). The statement was made by the president of the Executive Council of the Serb Democratic Party Bosnia and Herzegovina. 
(Cigar 1995, p. 32). The article, titled "Peace, Yes, But What Kind of Peace?" implies a rejection of a temporal peace in favor of an eschatological one that Serbians have an obligation to bring about. The author, Božidar Mijač, liberally uses religious imagery and metaphors to sanction the conflict:

“... [P]artisans of peace help the evil forces that are opposed to God (and by the same token humanity) and they are the champions of treason and defeat. In our present Armageddon, they are on the side of the destructive Gog and Magog (the mythical personifications of enslavement and tyranny)... [the conflict is a] self sacrificing struggle for the purpose of bringing about this [state of] righteousness is a highly creative impulse and a contribution to the fulfillment of God's and mankind's goals against evil and oppression as part of the universal plan of salvation". ((Mijač, "Mir, da ali kakav?"), quoted in (Cigar 1995, p. 32))

The capabilities of religious expression (collapsing of time and sustaining contradictions through ritual and myth) as well as religious histories (referencing past religious clashes and origin stories of Serb divine chosenness) were enlisted to buttress the credibility of the Bosnian Muslim threat and to justify extreme measures against it. These historical memories do not exist in a vacuum nor are they automatically operative in the popular imagination; they gain their sacral and enduring potency through Church propagation and ritual:

The Serbian Orthodox Church and the Catholic Church enjoy an enormous prestige in 'their' respective societies. If a certain version of history is spread from the pulpit, it easily acquires a dignity it has not had before transforming it into sacred history. The myth of Serbs and Croats as centuries-long victims needs constant renewal, if it is to survive. For so far [sic], the Churches have provided solid fuel for its survival. (Buchenau 2009, p. 17)

The cumulative effect of this prestige is that "as a rule, political decisions and military operations received religious legitimation and were openly supported by some religious media and in public statements made by religious dignitaries. Thus, they were exalted as actions, for example, in the name of God" (Velikonja 2003, p. 32). Therein, lies the ultimate justification, enhanced by the ultimate authority. Sells summarizes the religious justificatory and motivating components of the violence through what he terms a "symbolic matrix" of mythic time (the 1389 Battle of Kosovo), sacred space (Kosovo as the most sacred for Serbs), historical memory (the killing of Serbs during World War II), and a sophisticated ideology (the contention that Slavic Muslims are Turks and Christ-killers) (Sells 2001, p. 181). An embellished and modified version of these factors appears here, in service to arguing that claims of a sanctified Serbian people and land, rehearsed within biblical narratives and tropes, was coupled with collapsed time in order to create an urgency in fending off the imminent threat of Bosnian subjugation.

A sacred people and a sacred territory: Again, the primary justification for genocide was an ideology steeped in defense against a Muslim fundamentalist aggressor (who was a Serbian Orthodox apostate by converting during the Ottoman regime) bent on waging a jihad (a holy war with the intent of bringing non-Muslims under Muslim rule) and subjugating the "heavenly people" of the "heavenly state" to the authority of sharia (Islamic religious law). ${ }^{8}$ For example, long before Milošević's regime, in 1986, the Serbian Orthodox Church published the following claim: "It is no exaggeration to say that planned GENOCIDE is being perpetrated against the Serbian people in Kosovo!" (Sells 2001, p. 199, n. 10, emphasis in original), and during a 1987 synod of the Serbian Orthodox Church, the Church used the word "genocide" to characterize the killing of Serbians in Kosovo. A year later, Bishop Jovan of Sabac-Valjevo refers to Serbia as "without any doubt ... the greatest heavenly state" juxtaposed to

8 This accusation was inspired by the 1970 Islamic Declaration, written by then lawyer and later the president of Bosnia in 1989, Alija Izetbegović. The declaration was republished in 1990 by Serb nationalists, and Izetbegović contended that the foundations of a just Islamic state were irreconcilable with other political arrangements. 
a reference to the slaughtering of Serbians by Croatian Ustaše during World War II (Semelin 2007, p. 86). Semelin makes the following observation about the summary effect of such statements:

a religious rhetoric borrowed from Christianity [that] was grafted on to this attitude of total victimhood, ... experiences of suffering ... like those borne by Christ, transfigured the story of Serbia ... Church representatives [took] up the theme of a 'Heavenly Serbia' [that] would one day rise again, like Jesus Christ ... [I]t is the context in which this religious rhetoric was used that gave it such ferociously destructive potential. (Semelin 2007, p. 86)

By way of denying that Serbian forces were operating killing and rape camps and obliterating mosques, the Holy Episcopal Synod, "in the name of God's truth and on the testimony from our brother bishops ... [and] other trustworthy witnesses", released a document in 1992 castigating the European community for not interceding on behalf of Serbs who were victims of genocide in Bosnia-Herzegovina (Sells 1996, p. 84). In this context not only must the Serbian population be defended against slaughter, its status in the world as a divine people of divine territory, not unlike that of Jews as a chosen people and a "light unto the nations", must also be preserved. It is not a coincidence that Kosovo is referred to as the "Serb Jerusalem". Such rhetoric is "not just a religionization of politics", but also represents Serbs as "the defenders of the Christian tradition itself"; as Bosnian Serb nationalist Radovan Karadžić stated in a 1993 interview, [the] West will be grateful to us some day because we decided to defend Christian values and culture" (Johnston and Eastvold 2004).

Biblical narratives and religious symbolism: Situating the Christian Serbian-Bosnian Muslim conflict within a religious, and even at times biblical, narrative exacerbated tensions and added a metaphysical dimension to the conflict, conveying the physical and spiritual matters at stake. Concurring with sociologist Leo Kuper, Cigar insists that the development of an ideology is essential to justifying behavior that would otherwise be criminal (Cigar 1995, p. 22), and both Cigar and Sells agree that " ... religious mythology was necessary for motivating and justifying [the Bosnian] genocide, but it was not sufficient. To be effective, it needed to be combined with three years of systematic manipulation of the army, secret police, religious-nationalist militias, and the media". (Sells 2001, pp. 185-86) From its inception, Serb propagandists claimed that the genocide was "a necessary evil which had to be carried out in order to save the rest of Europe "from the virus of Islamic fundamentalism". (Khan 1997, p. 298)

Echoing Eric Hobsbawm, Mitja Velinkoja formulates what he contends is the outcome of demagogues justifying "their policies not only as a defense of their own nation, but also as shields ... [in the case of the Serbs] of the Orthodox world:

If one's faith is the only right and righteous one, then that of the enemy is scorned as being false, foreign, heretical, superstitious, and even sacrilegious. According to this logic of symbolic diades, the elimination of other faiths, religious and ethnic cleansing, becomes a religious duty; killing is no longer considered as homicide, but as a "malicide", the liquidation of the evil. (Velikonja 2003, p. 33)

Likewise, the 44th Patriarch of the Serbian Orthodox Church, His Holiness the Archbishop of Peć, Metropolitan of Belgrade and Karlovc, Serbian Patriarch Pavle (known more commonly as Patriarch Pavle), also branded Muslims as evil. Patriarch Pavle initially championed the government and promoted Serb nationalism during the 1991-1995 Balkan War. Although the relationship between Pavle and Milošević eventually soured, it was not until the conflict was well underway. Expressing his support of the war, Patriarch Pavle lends credence to his claim that war is justified by referencing the biblical narrative of Cain and Abel: "Evil always attacks, and good must defend itself ... . Cain always tries to kill Abel, and Abel has to defend himself. Defending oneself against attacks by wrongdoers, defending one's life, life and the peace of one's nearest and dearest against the criminals. These are the limits that define a just war" ((Radić 1998, p. 137), quoted in (Semelin 2007, p. 87)). Perhaps one of the most disturbing biblical references was not in the form of words but actions, as Bosnian children were crucified in front of their parents onto trees and wooden crosses". (Khan 1997, p. 287) 
Serbian Orthodox extremists invoked their own religious imagery complemented by denigrating the religious symbols and observances of the enemy group, which further communicated the righteousness and sanctimoniousness of the justness of Serbian nationalist retaliation. Keith Doubt asks if it was "an accident that in Sarajevo in 1992 nationalist Serbs started shelling the city during the festival of Bajram?" (Doubt 2000, p. 51). Perhaps it was not. Bajram is the paramount feast in the Islamic calendar that remembers Abraham's willingness to sacrifice his son, Ishmael, ${ }^{9}$ at God's behest. God substitutes a ram for Ishmael in response to Abraham's unequivocal compliance. Is it possible that nationalist Serbs were so assured of their justification in destroying Bosnian Muslims that bombing Sarajevo on Bajram was not only an added indignity but also a form of necessary scapegoating, a sacrifice? By Kenneth Burke and Jacques Semelin's lights, could the timing of the bombing have been ritually symbolic?

Serb génocidaires used Christian religious symbolism to reinforce the righteousness of their cause as well as denigrated Islam in an attempt to obliterate the metaphysical, physical, and historical existence of Muslims. Per ICTY transcripts, during military operations or subsequent conquests, 1000-1100 mosques were ruined, compared to approximately 340 Orthodox and 450 Roman Catholic churches and monasteries (Velikonja 2003, p. 33). Religious symbols and buildings were so central to the fabric of Bosnian culture that the destruction of mosques would severely undermine any attempts by the Bosniak community to reconstitute itself in Bosnia, even if many members physically survived.

Mythic time. The collapsing or fusion of time is taken up by several scholars, such as Sells (Sells 1996), and Lieberman (2006). The latter scholar lucidly outlines how national narratives can facilitate violence using Ivan Čolović's point that national narratives, which are a species of mythic time, create "a direct, living connection with the past" as a point of departure:

National hate narratives typically refer to the past, but they are most destructive when they shape interactions in the present. Under these conditions the stories of betrayal and victimization retold in nationalist narratives culminate, not with memories of past atrocities, but with charges of contemporary violence and betrayal. Historical time and everyday time, or past and present, collapse together. As a figure in a historical narrative, the individual neighbour, classmate, teammate or acquaintance, becomes a member of an inherently evil group that deserves destruction. This fusion of historical and everyday time creates meaning for acts that would normally be regarded as criminal. (Lieberman 2006, p. 300)

To lend credibility to threat that Catholic Croats and Bosnian Muslims posed to Serbs, ideologues revived past animosities and memories of genocide through public speeches and ceremonies in order to substantiate their case that a current genocide against Serbs was underway, making 14th century references to frame the current situation. The week prior to the Vidovdan celebration in Kosovo on June 28, 1989 commemorating the six-hundredth anniversary of the epic battle between Orthodox Serbs and Slavic Muslim armies at Kosovo Polje, Serbs made a pilgrimage to Gracanica monastery to honor and pray before the relics of Prince Lazer. The day of Vidovdan, Milošević made a speech on the plain of Gazimestan, the site of the Kosovo battle and near the monastery. Though not a particularly religious man but certainly a politically opportunistic one, he asserted that "Serbia was 'the bastion that defended the European culture, religion, and European society in general.' Although the mention of religion in this speech is brief, the subtext is obvious, that Serbia was the last bastion of Christian Europe against the Muslims" (Herzfeld 2007, p. 111).

The convergence of past and present in the Balkans and in Europe is also made clear in a speech delivered by Dubak Budimir at the First Conference of the Balkans in Athens in 21-24 May 1992:

Who of the rulers or commanders in chief of any army, except King Lazar, deliberately for the everlasting glory and immortality, between the kingdom on the Earth and the 
heavenly kingdom, chose the latter? With that sacrifice the Serbian peoples entered the great historic peoples of Europe. Whether Europe admits it or not. The Christian Europe and the Orthodox faith were defending themselves from the [sic] Islam religion on the Kosovo field in 1389. The French were aware of that, but today they have forgotten it, and ... France and united Europe led by Germany support the creation of the first [sic] Islam country at the heart of the Balkans, in Bosnia. Has the Serbian people deserved that? Is that the gratitude for the immense efforts for [sic] the Christianity and for Christ that they have done? (Khan 1997, p. 298))

The symbolic impact of relics, in this case, the bones of Serb King Lazar, also blurred the past and present together. His bones were disinterred in 1986, and three years later were paraded through the streets of Kosovo and Bosnia, an explicit tactic meant to link the fourteenth-century threat of Ottoman Turks to the present-day threat of Muslims to Serbs as well as to Serbian victims of the Croatian Ustaše (Lieberman 2006, p. 303). ${ }^{10}$ A thorough understanding of the inextricable link between the Kosovo myth, the Orthodox Church, and the emergence of Serbian national identity in opposition to a Muslim "other" accounts for how many Serbs felt they were genuinely exacting revenge in Bosnia Herzegovina against the "Turks".

\section{Authorization}

The authority, or invested right, to exterminate the enemy group was reinforced by the magnified influence of political figures, primarily Milošević, who were styled as Christ-like figures and heroes of the faith. Furthermore, the public claims and actions of Serbian Orthodox Church leaders whose role as spiritual guarantors and divine ambassadors, carried a moral and righteous weight, lending a "mantle of respectability to even the most extreme nationalist elements". (Cigar 1995, p. 67) The Serbian Orthodox church further condoned violence through official publications and speeches supporting the nationalist government and antipathies toward Muslims (including an admonishment of Serb pacifism) and aiding genocidal operations through logistical and moral support, even at times leading cleansing activities. On several occasions, political elites cited the invaluable assistance of the Serbian Orthodox Church in achieving their aims.

The deification of key actors: Political and military figures, already invested with the authority of the state, had their authority greatly enhanced through a process of apotheosis facilitated by strategic public appearances and religiously laden comments as well as the public commendations of Serbian Orthodox officials. At the 1989 Vidovdan celebration, Milošević stood in the same battlefield where the Christ-figure Lazar met his end and in close proximity to the monastery that housed his relics. In case the association was not obvious enough, there were posters for sale at the commemoration "depicting Christ, Prince Lazar whose promotion of ethnic cleansing and genocide carried the weight of the morality, and Milošević himself, as a new iconic Trinity". ${ }^{11}$ Another semi-deification is the wedding of the militia leader Željiko Raznjatović (better known as Arkan). The ceremony was replete with religious symbolism; he wore a Montenegrin warrior outfit with an imposing cross and his celebrity bride was dressed as the "The Maid of Kosovo", a Mary Magdalene figure in Serbian religious iconography who nurses martyrs on the battlefield (Sells 1996, p. 82). "This use of religious symbolism entails the implication, stated by Arkan himself, that 'we are fighting for our faith"'. (Herzfeld 2007, p. 111) Similarly, Metropolitan Nikolaj, the primate of the Orthodox Church in Bosnia, asserted, during Easter of 1993 "that those who accepted the leadership of Karadžić and Mladić were 'following the difficult road of Christ.'" the difficult road of Christ (Herzfeld 2007, p. 111). A year later, Karadžić proclaimed, "Our faith is present in all our thinking and decisions, and the voice of the Church is obeyed as the

10 See also (Sells 2001).

11 (Malcolm 1996, p. 213), quoted in (Herzfeld 2007, p. 111). 
voice of supreme authority", and at a Serb Democratic Party rally held in Sarajevo's Zetra stadium, Karadžić proclaimed, “Tonight even God is a Serb!” (Herzfeld 2007, p. 111)

The moral authority and support of the Orthodox Church: A spate of expositions of the Balkan Wars agree that the wars of ethnic cleansing and genocide were religious conflicts, in the sense of being motivated by Serbian Orthodox theology and rivalries among ethnoreligious groups. Yet a few of the scholars of these expositions also claim that the Orthodox Church leaders did not directly support ethnic cleansing or that the Church was not an ally of Milošević's (Herzfeld 2007, p. 111), which is simply not the case. However, to be fair, it is true that some clergy denounced Milošević and his policies throughout his tenure and that others later withdrew their support, but this break may have been due to Milošević being uninterested in carving out a prominent place for the Church in his "Greater Serbia" rather than to ethical objections, per se. ${ }^{12}$ Most of the church officials who denounced the violence still supported nationalist sentiments, and the few condemnations were sporadic and untimely. Religious leaders failed to mobilize their "natural constituency" for the purposes of nonviolent action as well as to provide a counter narrative to the "folk religion" of the "religiously illiterate population", or what Appleby understands to be a "low level or virtual absence of second-order moral reflection and basic theological knowledge among religious actors". (Appleby 2000, p.69) ${ }^{13}$

\section{Conclusions}

The guiding typologies of "othering", justification, and authorization are useful for sifting through the ways in which religious rhetoric and individuals intersected with genocidal propaganda and campaigns in Bosnia. To be sure, the dynamic of genocide is complex and the function of religion in this dynamic is various. Genocide architects and perpetrators used religious symbolism and rhetoric in many forms to "religionize" the Balkan Wars of the 1990s, and its primary effect was making the violence of genocide, ethnic cleansing, and sexual violence acceptable means for dealing with an Islamic threat by heightening the emotions and stakes around the conflict. Whether militants, the faithful, or the nominally religious believed the content of their religious rhetoric is debatable. Propagandists interjected religious myths, rituals and observances into military life and national discourse that demonized Bosnian Muslims, and sacralized their annihilation, enhanced by the high profile of political figures who were quasi-apotheosized. Church officials and their fellow coreligionists actively participated in the decisions and genocidal actions of Serb nationalists, conveying that the conflict was of religious import and met with God's approval (Velikonja 2003, p. 26), whether in the interest of the state, their own interests, or both. The wars in the Balkans were "religious if not by its inner content then by its external appearance", 14 and some argue that the Serbian Orthodox Church could have prevented rather than abetted the atrocities committed in the republics of the former Yugoslavia.

In addition to espousing and supporting state-sponsored genocide, the Serbian Orthodox Church was at times a site for planning campaigns of ethnic cleansing; it was also a site of ethnic cleansing operations and perpetration. In 1992, the local church in Brčko, a town in northern Bosnia and Herzegovina, was the site of one of the most devastating massacres of the Balkan Wars. The Church acted as a base for killing, body disposal, and concentration camp operations, all overseen by the self-proclaimed "Serb Adolf", Goran Jelisi (Sells 2001, p. 188). Church officials also blessed weapons

12 Klaus Buchenau contends that "later, the Orthodox Church backed Milošević's policies that aimed at a reserbianization of the province. But from the beginning of the 1990s, the Church grew more and more disappointed with Milošević because he proved unwilling to accept a major role of the church in society" (Buchenau 2009, p. 5).

13 Also, although this point will not be taken up here, it is important to note that this "folk" religion includes a class element. Folk religion is most prominent among rural peoples, and a point of pride of Serbian nationalism is that it has a "... distinct antiurban element"; Muslims were further demonized by as "city dwellers, contrasted to Serbian peasants" (Kiernan 2007, p. 592).

14 (Djordjević 1998, p. 156). Contra Djordjević, the view of the Bosnian war as "religious" is not shared by all authors on the subject, see, for example, Dimitrije M. Kalezić, who primarily believes the war was neither a religious or an ethnic one but a civil one (Kalezić 1998). 
and forces, conducted formal rituals in recognition of the successful ethnic cleansing of towns, and supplied chaplains to and fostered the morale of the Bosnian Serb Army by not only spearheading cleansing operations but making public statements such as, "we have always won the wars ... God will not abandon us this time either". ${ }^{15}$ Arkan, commander of the paramilitary Serb Volunteer guard and whose men allegedly committed a number of atrocities in Bosnia-Herzegovina, stated in an interview that he "received initial help 'above all" ... from the Serbian Orthodox Church in organizing, financing, and arming his militia (Cigar 1995, p. 36).

If perpetrators of the Bosnian genocide viewed the support of the Serbian Orthodox Church as integral to their campaign, it may well be argued that the Church could have been a significant factor in stymieing the genocide. The ambivalent nature of religion makes its incendiary genocidal potential as powerful as its genocidal obviating potential:

[E]ven if religion was not a root cause of the conflict ... its implications for the issues of ultimate reality that influence people's identities and behavior are significant and need to be addressed. By ignoring generally religious issues, ... [it] not only inhibit[s] a correct diagnosis [of conflicts] but also overlook[s] (if not spurn[s]) the assistance of possible allies within the religious traditions in question. (Johnston and Eastvold 2004)

Moreover, in Accounting for Genocide: National Responses and Jewish Victimization During the Holocaust (1979), Helen Fein "demonstrates [that] the involvement or resistance of religious institutions in genocide can have a profound impact on the success or failure of genocidal movements" (Longman 2010, p. 17, my emphasis). "The idea of engaging religious leaders and organizations in order to resist the spread of genocide has been ignored by those working in the growing field of genocide prevention", (Tuckwood 2007) and it is imperative to bring to bear any and all resources, especially local ones, that are formidable enough to stymie, ameliorate, or even halt genocide once it commences. A critical part of these local resources are church officials and the institutional church. Recognizing the potential of religion to prevent and mitigate genocide is to acknowledge the capability of religious discourse, actors, and institutions to be positive rather than negative forces in conflicts.

The typologies of "othering", justification, and authorization, then, represent not only ways of teasing out how religious rhetoric, myths, and actors promote genocide by providing recognizable narratives of ultimacy and raising the stakes of conflict but also how these typologies also point toward a strategy for prioritizing how religious traditions and church officials can act as a bulwark against genocide. Illustrations include humanizing rather than demonizing the "other", utilizing religious rhetoric to provide counter-narratives to ostensibly justified violence, and exercising the moral reach of the church to condemn violence and promote reconciliation. Regarding the latter, in 1996, Sells succinctly captured the importance of examining the role of religion in genocide in the Balkans, not only for understanding the genocide but also as a basis for moving forward in the region, when he argues that

[f]uture decisions regarding policy toward the Balkans should take into consideration the Kosovo mythology, how it was manipulated and continues to be manipulated. [Moreover], to "adequately acknowledge the role and power of Kosovo's mythology entails a recognition that religion is not necessarily confined to the self-conscious articulations of private faith or piety but has social aspects, mediated through symbols and myth, that can act, with massive power, upon a society as apparently secularized as the communist Yugoslavia of 1989. (Sells 2001, p. 198)

15 (Cigar 1995, p. 68). The statement was made by a Serbian Orthodox metropolitan of Bosnia, Nikola, and a priest in Trebinje incited and led local Serbs in the raid and takeover of a number of Muslim occupied apartment and Muslim owned businesses. 
It has now been over twenty years since signing of the Dayton Peace Accords in 1995, and the current reality in Bosnia-Herzegovina is that of a country gripped by genocide denial, failed truth and reconciliation commissions, and political competition for ethno-nationalistic dominance (Hodžić 2015; Porobic-Isakovic 2016; Dragovic-Soso 2016). Refik Hodžić contends that this reality is "a war fought by 'other means ... in political arenas, but also in the media, in classrooms, churches and mosques, [and] at family dinner tables, and its consequences are bound to have a lasting impact on the region's stability". The part that religion has and can play in reconciliation is a mixed one. Despite the negative role that prominent religious leaders have played in reconciliation, it appears that the a majority of those living in Bosnia-Herzegovina, who identify both as religious and non-religious, believe that religious leaders and lay people have a significant role to play in reconciliation efforts. ${ }^{16}$ This appears to further substantiate the powerful influence that religion has on both the religious and non-religious. Just as the force of religious rhetoric can persuade both the religious and non-religious that genocide is permissible, this same force of religion is recognized by the religious and non-religious as important to overcoming the animosities that stands in the way of reconcilement.

Well after the war's end and during an ICTY proceeding religious figures continued to perpetuate the wars of Yugoslavia as being of sacred and biblical proportions. On 21 February 2008, Metropolitan Amfilohije of Montenegro (Radović), the bishop of the diocese of Montenegro, on numerous occasions expressed his hostility toward non-Serbs and iterated the duty to fight during a sermon at St. Sava's Cathedral in Belgrade in the presence of 300,000 Serbian Orthodox. Additionally, Radović "announced that the Serbs could not renounce Kosovo neither in this world nor in afterlife, and that they should fight for it until the end of time, even at the price of death", essentially couching what is essentially a this-worldly struggle in cosmic time, a message further reinforced by his status as a bishop (Buchenau 2009, p. 6). Amfilohije also delivered a telling sermon in the Montenegrin village Krnja Jela, where

he formulated what he [thought] to be the Christian essence of the story [the ICTY trial of Serbian defendant Radovan Karadžić]. Amfilohije stressed that everything positive in Serbian culture was built on the sacrifice for truth, justice and one's neighbor, and that "still today the best sons of this people sacrifice themselves. They are brought (...) to courts where they are judged by those who are indefinitely worse than they. Just as those who judged Christ on Golgotha". (Buchenau 2009)

A twin consideration, and a little-explored facet of the motivation for genocide is to what extent the organized Church viewed genocide or ethnic cleansing as advancing their own interests, even if the genocide was not initiated by the Church. Douglas Johnston and Jonathan Eastvold make the case that the Serbian Orthodox Church "gave conditional support to the Serbian political leadership—not because it wholly agreed with it, but rather out of pastoral concern for the Serbian people [due to] legitimate Serbian concerns about Islamic rule in Bosnia and Kosovo". They cite this November 1994 statement by the Holy Synod to illustrate their claim: "[We] do not consider ourselves identical with the governments on either side of the Drina River but we cannot separate ourselves from our, although sinful [sic], nevertheless still a People of God in the ecumenical family of peoples, but stay with them on the cross upon which they are crucified" (Johnston and Eastvold 2004). Even if Johnston and Eastvold are correct, this does not mean that the Church lacked the desire to secure an influential role with the state. ${ }^{17}$ Another roadblock to reconciliation efforts appears in a 2009 report, "The Current Status of Religious Coexistence and Education in Bosnia and Herzegovina", which reads, "despite 15 years of sporadic efforts, religion today in Bosnia and Herzegovina is more of a hindrance than a help to promoting peaceful coexistence" (Stuebner 2009). Citing religious polarization and

16 In 2013 study, 54.3\% of overall respondents believed that religious figures were either "very important" or "important" to the reconciliation process in Bosnia-Herzegovina. (Wilkes et al. 2013).

17 For a chronicle of the Serbian Orthodox Church's marginal societal status and reentry into the political sphere between 1980 and 1995, see (Radić 1998). 
extremism, the report pinpoints that the Inter-religious Council in Bosnia-Herzegovina "is attempting to implement worthwhile programs, [but] most of the top religious leaders are more interested in promoting the interests only of their own co-religionists or in furthering other political agendas" (Stuebner 2009).

Interestingly, these setbacks seem to be tempered by a hope among the international community and citizens of Bosnia-Herzegovina that religion can still positively impact the reconciliation process.

In promoting interreligious interactions, a United States Institute of Peace Special Report on Bosnia and Herzegovina claims that "where there is a lack of strong popular engagement ... clerics may lead by example" (Peuraca 2003, p. 4). Moreover, a report, "Factors in Reconciliation: Religion, Local Conditions, People and Trust. Results From A Survey Conducted in 13 Cities Across Bosnia and Herzegovina in May 2013" (Wilkes et al. 2013), reveals that the majority of respondents believe that religion can play an important part in healing the country.

The study had a sample size of 2,060 respondents from 13 cities across Bosnia-Herzegovina who answered 78 questions in writing related to reconciliation efforts (Wilkes et al. 2013, p. 5). An expressed affiliation with religious traditions indicated that the "sample was comprised of $35.0 \%$ Muslims, 30.7\% Orthodox, $23.8 \%$ Catholics, $1.9 \%$ agnostics, $3.4 \%$ atheists, $1.5 \%$ members of other churches and religious communities, and 2.7\% chose not to respond to this question". (Wilkes et al. 2013, p. 13) When asked "How important would prominent religious figures be for a reconciliation process designed to build trust and understanding across the population of $\mathrm{BiH}$ ?" $33 \%$ of respondents answered "very important" and 25\% responded "important". (Wilkes et al. 2013, p. 23) Similarly, when asked "How important would lay believers be for a reconciliation process designed to build trust and understanding across the population of $\mathrm{BiH}$ ?" $26 \%$ reported "very important" and $30 \%$ reported "important". (Wilkes et al. 2013, p. 24) Strikingly, the overall sample that completed the questionnaire indicated that religious leaders were seen as more important to reconciliation and building trust than politicians (54.3\% and $48.6 \%$, respectively) (Wilkes et al. 2013, p. 6). What the study suggests is that religion can be advantageous to the reconciliation process, which is also pivotal to genocide prevention, as unresolved tensions and ignored grievances among communities can provide a breeding ground for future conflicts (Beachler 2011).

Conflicts of Interest: The author declares no conflict of interest.

\section{References}

Alvarez, Alex. 2001. Governments, Citizens, and Genocide: A Comparative and Interdisciplinary Approach. Bloomington: Indiana University Press.

Appleby, R. Scott. 2000. The Ambivalence of the Sacred: Religion, Violence, and Reconciliation. Lanham: Rowan and Littlefield Publishers.

Ball, Patrick, Ewa Tabeau, and Philip Verwimp. 2007. The Bosnian Book of the Dead: Assessment of the Database (Full Report). Falmer: The Institute of Development Studies. Available online: https://hrdag.org/wpcontent/uploads/2013/02/rdn5.pdf (accessed on 3 January 2015).

Bartov, Omer, and Phyllis Mack. 2001. Introduction. In In God's Name: Genocide and Religion in the Twentieth Century. Edited by Omer Bartov and Phyllis Mack. New York and Oxford: Berghahn Books, pp. 1-22.

Basic, Goran. 2017. Concentration Camp Rituals: Narratives of Former Bosnian Detainees. Humanity \& Society 41: 73-94. Beachler, Donald W. 2011. The Genocide Debate: Politicians, Academics, and Victims. New York: Palgrave Macmillan, p. 93. Berger, Peter L. 1990. The Sacred Canopy: Elements of a Sociological Theory of Religion. New York: Anchor Books Doubleday. Buchenau, Klaus. 2009. The Churches and the Hague Tribunal: A Serbian Orthodox and a Croat Catholic Perspective. Forschungsplattform Südosteuropa. Available online: http://www.google.com/url?sa=t\&rct=j\&q=\&esrc= s\&source=web\&cd=1\&cad=rja\&sqi=2\&ved=0CDUQFjAA\&url=http $\% 3 \mathrm{~A} \% 2 \mathrm{~F} \% 2 \mathrm{Ffpsoe} . \mathrm{de} \% 2 \mathrm{Ffileadmin} \%$ 2FPDFs_Beitraege\%2FFPSOE_Buchenau_Churches_and_ICTY.pdf\&ei=fABIUY31N4XWygGSvIDoCw\&usg= AFQjCNGJscQAzOk0ITDfeQ4jAiRvZqDFww\&sig2=uI_eTDPONUzp-k1nKAi68w\&bvm=bv.44990110,d. aWc (accessed on 10 April 2013).

Cigar, Norman. 1995. Genocide in Bosnia: The Policy of "Ethnic Cleansing". College Station: Texas A\&M University Press. 
Djordjević, Dragoljub. 1998. Serbian Orthodox Church, the Disintegration of Second Yugoslavia, and the War in Bosnia Herzegovina. In Religion and the War in Bosnia. Edited by Paul Mojzes Atlanta: Scholars Press.

Doubt, Keith. 2000. Sociology after Bosnia: Recovering Justice. Lanham: Rowman \& Littlefield Publishers, Inc., p. 51. Dragovic-Soso, Jasna. 2016. History of a Failure: Attempts to Create a National Truth and Reconciliation Commission in Bosnia and Herzegovina, 1997-2006. International Journal of Transitional Justice 10: 292-310. [CrossRef]

Herzfeld, Noreen. 2007. Lessons from Srebrenica: The Danger of Religious Nationalism. Journal of Religion $\mathcal{E}$ Society 2: 110-16.

Hodžić, Refik. 2015. Twenty Years Since Srebrenica: No Reconciliation, We're Still at War. International Center for Transitional Justice. June 29. Available online: https:/ / www.ictj.org/news/twenty-years-srebrenica-noreconciliation-we $\backslash \mathrm{T} 1 \backslash$ textquoterightre-still-war (accessed on 4 June 2017).

International Criminal Tribunal for the Former Yugoslavia. 2005. Facts About Srebrenica. Available online: http://www.icty.org/x/file/Outreach/view_from_hague/jit_srebrenica_en.pdf (accessed on 4 January 2015).

Jacobs, Steven Leonard. 2009. Introduction: Genocide in the Name of God: Thoughts on Religion and Genocide. In Confronting Genocide: Judaism, Christianity, Islam. Edited by Steven Leonard Jacobs. New York: Lexington Books.

Johnston, Douglas, and Jonathan Eastvold. 2004. Religion in the Bosnian Conflict. International Center for Religion and Diplomacy. Available online: http://icrd.org/rp24/ (accessed on 8 October 2013).

Jowett, Garth S., and Victoria O'Donnell. 2006. Propaganda and Persuasion. Thousand Oaks: Sage Publications.

Judah, Tim. 2000. A Brief History of Serbia. In Kosovo: Contending Voices on Balkan Interventions. Edited by William Joseph Buckley. Grand Rapids: Wm. B. Eerdmans Publishing Co., pp. 89-96.

Kalberg, Stephen. 2012. Max Weber's Comparative-Historical Sociology Today: Major Themes, Mode of Causal Analysis, and Applications. Burlington: Ashgate Publishing Company, p. 130.

Kalezić, Dimitrije M. 1998. The Serbian Orthodox Church's View of the Role of Religion in the War in Bosnia Herzegovina. In Religion and the War in Bosnia. Edited by Paul Mojzes. Atlanta: Scholars Press.

Khan, Mujeeb R. 1997. Bosnia-Herzegovina and the Politics of Religion and Genocide in the 'New World Order'. Islamic Studies 36: 287-327.

Kiernan, Ben. 2007. Blood and Soil: A World History of Genocide and Extermination from Sparta to Darfur. New Haven: Yale University Press.

Lieberman, Ben. 2006. Nationalist Narratives, Violence between Neighbours and Ethnic Cleansing in Bosnia-Hercegovina: A Case of Cognitive Dissonance? Journal of Genocide Research 8: 295-309. [CrossRef]

Little, David. 1991. Ukraine: The Legacy of Intolerance. Series on Religion, Nationalism, and Intolerance; Washington: United States Institute of Peace Press.

Longman, Timothy. 2010. Christianity and Genocide in Rwanda. New York: Cambridge University Press, p. 17.

Malcolm, Noel. 1996. Bosnia: A Short History. London: Papermac.

Mihailovich, Vasa D. 1991. The Tradition of Kosovo in Serbian Literature. In Kosovo: Legacy of a Medieval Battlefield. Edited by Wayne S. Vuchinich and Thomas A. Emmert. Minneapolis: University of Minnesota, p. 141.

Paul, Mojzes. 1998. Religion and the War in Bosnia. Atlanta: Scholars Press.

Peuraca, Branka. 2003. Can Faith-Based NGOs Advance Interfaith Reconciliation?-The Case of Bosnia and Herzegovina. Washington: United States Institute of Peace. Available online: http:/ /www.usip.org/sites/default/files / sr103.pdf (accessed on 21 December 2014).

Porobic-Isakovic, Nela. 2016. Transitional justice in Bosnia and Herzegovina-Challenges and opportunities. Ukranian Helsinki Human Rights Union. July 25. Available online: https://helsinki.org.ua/en/articles/ transitional-justice-in-bosnia-and-herzegovina-challenges-and-opportunities / (accessed on 4 June 2017).

Radić, Radmila. 1998. L'Eglise et la question serbe. In Radiographie d'un nationalisme: Les racines serbes du conflit yougoslave. Edited by Nebojsa Popov. Paris: de l' Atelier, p. 137.

Radić, Radmila. 1998. Serbian Orthodox Church and the War in Bosnia and Herzegovina. In Religion and the War in Bosnia. Edited by Paul Mojzes. Atlanta: Scholars Press.

Ragin, Charles C., and Howard Saul Becker. 1992. What is a Case? Exploring the Foundations of Social Inquiry. New York: Cambridge University Press.

Roth, John K. 2010. Easy to Remember? Genocide and the Philosophy of Religion. International Journal for Philosophy of Religion 68: 31-42. [CrossRef]

Sells, Michael. 1996. The Bridge Betrayed: Religion and Genocide in Bosnia. Berkeley: University of California Press. 
Sells, Michael. 2001. Kosovo Mythology and the Bosnian Genocide. In God's Name: Genocide and Religion in the Twentieth Century. Edited by Omer Bartov and Phyllis Mack. New York and Oxford: Berghahn Books.

Semelin, Jacques. 2007. Purify and Destroy: The Political Uses of Massacre and Genocide. London: Hurst.

Sherwood, Harriet. 2017. Pope Francis asks for forgiveness for church's role in Rwanda genocide. The Guardian. March 20. Available online: https:/ / www.theguardian.com/world/2017/mar/20/pope-francis-asks-forforgiveness-for-churchs-role-in-rwanda-genocide (accessed on 1 April 2017).

Stone, Dan. 2004. Genocide as Transgression. European Journal of Social Theory 7: 45-65. [CrossRef]

Stuebner, Renat. 2009. The Current Status of Religious Coexistence and Education in Bosnia and Herzegovina. Washington: United State Institute of Peace. Available online: http://www.usip.org/sites/default/files/religion_ education_bosnia_herzegovina.pdf. (accessed on 8 January 2015).

The United Nations International Criminal Tribunal for the former Yugoslavia. n.d. The Cases. Available online: http:/ / www.icty.org/en/action/cases/4 (accessed on 5 June 2017).

Tuckwood, Christopher. 2007. Engaging Religion in the Prevention of Genocide. Genocide Watch. Available online: http:/ / www.genocidewatch.org/genocide/articlesongenocide.html (accessed on 14 February 2014).

Udovički, Jasminka. 1995. Nationalism, Ethnic Conflict, and Self-Determination in the Former Yugoslavia. In The National Question: Nationalism, Ethnic Conflict, and Self-Determination in the Twentieth Century. Edited by Berch Berberoglu. Philadelphia: Temple University Press, p. 297.

United States Holocaust Museum. n.d. Holocaust Encyclopedia: Making a Leader. Available online: https: / / www.ushmm.org/wlc/en/article.php?ModuleId=10007817 (accessed on 5 June 2017).

Velikonja, Mitja. 2003. In Hoc Signo Vinces: Religious Symbolism in the Balkan Wars 1991-1995. International Journal of Politics, Culture, and Society 17: 25-40. [CrossRef]

Wilkes, George R., Ana Zotova, Zorica Kuburić, Gorazd Andrejč, Marko-Antonio Brkić, Muhamed Jusić, Zlatiborka Popov Momcčinović, and Davor Marko. 2013. Factors in Reconciliation: Religion, Local Conditions, People and Trust. Results From A Survey Conducted in 13 Cities Across Bosnia and Herzegovina in May 2013. Fojnica: Stamparija Fojnica. Available online: http:/ /www.ceir.co.rs/diskursi/uploads/2013/dec/ Edinburg\%20Eng.pdf (accessed on 4 June 2017).

(C) 2017 by the author. Licensee MDPI, Basel, Switzerland. This article is an open access article distributed under the terms and conditions of the Creative Commons Attribution (CC BY) license (http://creativecommons.org/licenses/by/4.0/). 